\title{
State liability for violation of European Union law-a Polish perspective
}

\author{
Nina Póltorak
}

Published online: 26 April 2012

(C) The Author(s) 2012. This article is published with open access at Springerlink.com

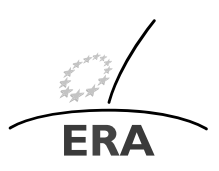

EUROPÄISCHE RECHTSAKADEMIE ACADEMY OF EUROPEAN LAW ACADEMIE DE DROIT EUROPEEN ACCADEMIA DI DIRITTO EUROPEO TRIER - TREVES - TREVIRI

\begin{abstract}
State liability for damage incurred as result of violation of European Union law is by now a well-established principle of European Union law. It is a principle still encapsulated in case law, the member states having chosen not to incorporate it into the primary law of the European Union. The principle has influenced national rules on the liability for damages and the case-law of national courts. This article aims to provide an overview of such influence on the Polish law concerning state liability. This process is visible in Polish law. However as will be indicated, the influence has been insufficient to guarantee either compliance of Polish legislation with European Union law or compliance with the principle of the effectiveness of Union law. This also relates to the case-law of Polish courts, as surprisingly, the European Union principle of liability for damages has enabled the courts to limit and restrict the interpretation of Polish law provisions. Yet so far there has been no case-law enabling the principle to be used to support the approach of Polish law under which the adoption of rules of liability favorable to the aggrieved party is enabled.
\end{abstract}

Keywords State liability - Compensation for damages · Polish law · Civil Code · Code of Civil Procedure 


\title{
1 The European Union principle of state liability
}

1.1. The right to obtain compensation for damages incurred as a result of European Union law violations stems from Union law. ${ }^{1}$ This means that it has to be guaranteed and protected in the national legal system even if national law does not provide for an equivalent right. Obviously, this right must be implemented through national law and procedures in accordance with the principle of procedural autonomy. ${ }^{2}$ However, in so far as the Court of Justice defines the prerequisites for liability, these have a common content, independent of national law, and they should be applied in a uniform way by national courts. The introduction into the national law of prerequisites for liability additional to those formulated by the Court of Justice, which make obtaining compensation "excessively difficult," is unacceptable. It is thus not permitted to substitute the prerequisites set out by the Court with national ones or to apply, in addition to the European Union conditions for state liability, domestic ones which do not fulfill the requirement of effectiveness and equivalence of protection (with the exception of situations when the state liability in the national law is based on less restrictive conditions). This is confirmed in the case-law of the European Court of Justice, according to which

\begin{abstract}
"a right to obtain redress will therefore arise where it has been established that the rule of law infringed is intended to confer rights on individuals and there is a direct causal link between the sufficiently serious breach of the obligation relied on and the loss or damage sustained by the injured party, since those conditions are necessary and sufficient to found a right for individuals to obtain redress".
\end{abstract}

1.2. However, all issues pertaining to adjudication upon member state liability for damages, both of a material and procedural character, that have not been decided in the case-law of the Court of Justice are left to be regulated by national laws. These laws must of course meet the conditions of non-discrimination (equivalence) and effectiveness. ${ }^{4}$

\section{Basis of state liability in Polish law}

2.1 The legal basis for state liability in Polish law is Article 77 of the Constitution of 1997, which states that "everyone shall have the right to compensation for any harm done to him/her by any action of an organ of public authority contrary

\footnotetext{
${ }^{1}$ Some aspects of this article can be found in Polish language in my work: Póltorak [10]. Polish legal writing on the European Union state liability principle is extensive, in particular: Górka [3], Pajor [5], Tokarzewska [15], p. 64; Póttorak [9] and subsequent; Sanetra [12], p. 9; Sanetra [13], p. 7; Sanetra [14]; Sadowski [11], p. 41; Zatorska [17], p. 7; Póttorak [6], p. 941-979; Póttorak [8], p. 462 and subsequent.

${ }^{2}$ W. van Gerven [15], p. 501-536; Kakouris [4], p. 389-1412.

${ }^{3}$ Case C-470/03, A.G.M. A.G.M.-COS.MET Srl vs. Suomen valtio and Tarmo Lehtinen [2007] ECR 2749.

${ }^{4}$ Case C-46/93 and C-48/93 Brasserie du Pêcheur and Factortame, [1996] ECR I-102, par. 67.
} 
to law." The right to compensation for unlawful action on the part of a state authority is thus a constitutional rule. However, after the introduction of this new rule, the detailed provisions of the given status and especially the Civil Code were still not in compliance with it. In 2001 this was even confirmed in the judgment of the Constitutional Tribunal, which repealed the basic provision of Civil Code providing that the proof of the fault of the given authority is required to make good damage. 5

2.2 In 2004, substantial amendments were finally introduced to these provisions of the Civil Code. ${ }^{6}$ Currently, the legal basis for state liability in Polish law consists of the amended provisions of the Civil Code (Articles 417-421). Those rules are unified now, whereas previously liability for administrative decisions was regulated separately. At present, liability arising out of any state authority's actions or omissions is governed by the provisions of the Civil Code. 2004 amendments introduced very clear provisions on liability for administrative, legislative and judicative actions and omissions. This approach is new as previously liability for judicial and legislative actions was almost excluded. The amendments also introduced new circumstances governing the State's liability - the right to redress arises in the event of unlawful action, damage (including loss), and a direct causal link between the action and the damage. An additional procedural requirement was also introduced to the effect that damages are to be claimed only if the unlawfulness of an action is stated in the course of appropriate proceedings. That means that the claim for damages is conditional on a preliminary ruling confirming that the action in question is against the law. As a rule, a court deciding a damages claim is not entitled to decide independently, on its own, that the action was against the law.

2.3 Those amendments introduced to the Civil Code just after the accession of Poland to the European Union, contained no reference to European Union law. Nor did the statement of reasons for those amendments. However, there is no doubt that they were partly inspired by European Union law and by the case-law of the European Court of Justice. Not referring to the European Union principle of state liability seems to be a rule in the legislative process. In the legislative work on the changes into Polish provisions pertaining to liability, this principle seems absent. In the explanatory statement for the basic amendments to the Civil Code and the Code of Civil Procedure, it is not even mentioned once. In the explanatory statement regarding the 2010 amendments to the provisions of the Civil Code and the Code of Civil Procedure referring to liability for state authorities, ${ }^{7}$ it was stated explicitly that the matters it regulated were not subject to European Union law, which may be considered true only if we understand "European Union law" in a very strict way as excluding the case-law of the European Court of Justice.

\footnotetext{
${ }^{5}$ Judgment of the Constitutional Tribunal of 4 December 2001, SK 18/00.

${ }^{6}$ Act of 17 June 2004 amending the Civil Code (Journal of Laws, 2004, No. 162, item 1692).

${ }^{7}$ Act of 22 July 2010 amending the act-Civil Code, the act-Code of Civil Procedure and the actBankruptcy and Reorganization Law (Journal of Laws, 2010, No. 155, item 1037).
} 
2.4 Taking into account the new provisions on state liability introduced in Poland in 2004, it seems that the regulation of state liability there is modern, effective, compliant with the Polish Constitution and inspired by European Union law. However, if we look into the details of this approach, a number of questions and doubts arise.

\section{Need for specific regulation of state liability?}

3.1 In the light of the case-law of the European Court of Justice it is not indispensable to introduce regulations pertaining directly to liability for European Union law infringement provided that the national provisions - applied in domestic casesare basically compliant with the principles of state liability formulated in European Union law. Nevertheless, judicial practice is of equal importance-i.e., whether domestic courts apply and interpret this domestic regulation in compliance with the Union principles.

3.2 European Union law does not exclude the existence of double standards in national law-one for compensation claims derived from the infringement of the national law, and a different one, though uniform and compliant with the Union standard, for claims derived from the infringement of European Union law. Thus Polish law may provide for different standards for claims derived from Union law and from domestic law. However, the Union standard has not been regulated in a holistic way in Polish law, and Union requirements illustrate vividly all the situations in which Polish law makers attempt to limit or exclude the state liability.

\section{Conditions for state liability and the equivalence and effectiveness principles}

4.1 According to the Court of Justice, regardless of the character of the legal infringement, the following prerequisites for state liability are to be considered: the rule of law infringed must be intended to confer rights on individuals, the breach must be sufficiently serious and there must be a direct causal link between the breach of the law and the damage incurred. ${ }^{8}$ If we then identify in Polish law some prerequisites for state liability that do not comply with those just indicated or some provisions regulating pursuit of claims which do not meet the requirements of equivalence and effectiveness, Polish law will not fulfill the obligations imposed by European Union law. According to the European Court of Justice, European Union claims for damages cannot be treated less favorably than similar domestic claims (the principle of equivalence). It is interesting to see if there are or could be any consequences to the European Union equivalence principle for the Polish rules on the state liability.

${ }^{8}$ Case C-46/93 and C-48/93, Brasserie du Pêcheur, par. 51. 
4.2 First of all, it must be underlined that there are examples in the jurisprudence of the Supreme Court on the application of the European Union principle of equivalence of protection. The Supreme Court stated that ignoring European Union law in a court judgment may constitute a gross infringement of the law justifying the declaring of a judgment unlawful on the same basis as this can be done in the event of the court ignoring Polish law. ${ }^{9}$

4.3 The liberal standard of liability introduced in Polish law will influence the standard for Union claims. According to the principle of equivalence, domestic prerequisites for liability, which are more favorable for the aggrieved party than Union prerequisites, should also be applied in adjudicating claims derived from European Union law (otherwise discrimination against a Union claim, as compared with a domestic one, may occur.) In Polish law, this may pertain to the prerequisite of unlawfulness. According to the case-law of the Court of Justice, qualified unlawfulness (sufficiently serious) is a condition for liability whereas in Polish law mere unlawfulness suffices. This liberal condition should therefore be applied to Union claims as well. In practice, however, qualified unlawfulness is understood in European Union law in a similar way to ordinary unlawfulness in Polish law.

4.4 The principle of equivalence of protection may also have unexpected effects. As will be explained later, the Supreme Court used the equivalence principle to justify a restrictive interpretation of the Polish provisions concerning the circumstances of liability. It stated that only manifest infringement of law in a court decision may give rise to the liability in damages.

4.5 The equivalence rule also had similar consequences in the judgments of the Constitutional Tribunal and the Court of Justice referring to Polish legislation incompatible with European Union law. This will be explained in point 8.2. below.

4.6 The other problem is the exclusion of liability for non-final decisions and judgments. The provisions of Civil Code do not exclude such liability clearly, but the prevailing interpretation (including the Constitutional Tribunal ${ }^{10}$ ), assumed that there is no right to obtain compensation for damage or loss resulting from non-final decisions or judgments. European Union law allows for mitigating or even excluding liability in the case of non-exhaustion of domestic remedies to avoid any damage, ${ }^{11}$ but Polish law excludes such liability as a rule irrespective of the circumstances. It might happen in case of the decisions or judgments of the first instance which might be immediately enforced, that the infringement results from the first instance (non-final) action infringing European Union law. In such cases, the interpretation approved by the Polish case law might be declared against the state liability rule in European Union law and the principle of effectiveness.

\footnotetext{
${ }^{9}$ The Supreme Court judgment of 8 December 2009, IBU 6/09- the case was about the omission by the court of Art. 18 of the EC Treaty.

${ }^{10}$ Judgment of Constitutional Tribunal of 1 April 2008, SK 77/06, OTK 2008, No. 3, item 39.

${ }^{11}$ Case C-445/06, Danske Slagterier v. Bundesrepublik Deutschland [2009] ECR I-2119, par. 60-62.
} 


\section{The requirement to have an action declared unlawful in an appropriate preliminary proceeding}

5.1 Provisions of the Civil Code make obtaining compensation basically conditional on having a given action performed by the state declared unlawful in "appropriate proceedings." (See Art. $417^{1} \S 1$ insofar as concerns normative acts; see $417^{1} \S 2$ insofar as concerns final decisions and final court judgments). That means that the claim for damages is conditional on the preliminary ruling confirming that the given action is against the law. The courts deciding a damages claim are, as a rule, not entitled to decide independently that the action complained of was against the law.

5.2 If the requirement of having an action declared unlawful constitutes in essence a prerequisite for liability to pay compensation, it should be assumed that it may not be applied in the case of claims derived from European Union law as, according to the Court of Justice, the circumstances for liability formulated in its case-law are necessary and sufficient for adjudicating on the question of liability. ${ }^{12}$ If we consider this requirement a condition of a procedural character, which seems more probable, then for the purpose of the evaluation of its compliance with European Union law, we should apply the tests of non-discrimination and effectiveness, which apply in European Union law to procedural limitations imposed in the domestic laws of member states which affect the execution of Union rights.

5.3 It is not clear that the requirement of having a final judgment or decision declared unlawful in appropriate proceedings is in itself compliant with the requirement that remedies serving the purpose of pursuing compensation claims should be effective. In the light of the case-law of the Court of Justice, a national court is entitled to adjudicate independently whether the prerequisite of unlawfulness has occurred. No direct conclusion follows from the case-law that it must be the same court which adjudicates on liability for damages, but such a conclusion may be derived from the statements on the independence of courts in deciding whether the circumstances for liability have occurred. ${ }^{13}$ In Polish law the possibility of independent qualification was excluded until 2010 and is still very limited. Serious doubts are raised by this requirement especially in the situation when there are no appropriate proceedings to have an action declared unlawful, which in fact blocks the right to obtain compensation.

5.4 Another doubt with reference to European Union law is whether proceedings before the Court of Justice will be considered appropriate proceedings, within the meaning of the Civil Code provisions. The Court of Justice of the European Union may declare a provision of law or "declare a judgment" issued by a Polish court "unlawful" in the course of these proceedings (something which may take place under Article 258 of the TFEU, ${ }^{14}$ or indirectly in preliminary rul-

\footnotetext{
${ }^{12}$ Case C-470/03, A.G.M.-COS.MET. Sanetra [12], p. 9 seems to opt for recognizing this requirement as a prerequisite for liability.

${ }^{13}$ Case C-46/93 and C-48/93 Brasserie du Pêcheur, par. 94 et seq.

${ }^{14}$ Case C-154/08 Commission v. the Kingdom of Spain [2009], ECR I-00187.
} 
ing proceedings). Such a judgment by the Court of Justice should be considered equivalent to a judgment of a Polish court declaring a decision unlawful. ${ }^{15}$

\section{Preliminary procedure in the case of liability in respect of court decisions}

6.1. The requirement of a preliminary ruling establishing unlawfulness exists irrespective of the source of the infringement. In case of administrative decisions the appropriate proceeding is understood to be extraordinary appeal proceedings from final decisions. In the case of the legislative acts, such proceedings should take place before courts entitled to declare the provision of law unlawful (see point 8 below).

6.2. In case of judicial decisions, the appropriate proceeding is considered to consist of extraordinary appeals from the final judgments. As such extraordinary appeals are very limited, a need existed to introduce a special kind of procedure in which it would be possible to state the unlawfulness of the judgment. A special proceeding was introduced into the Code of Civil Procedure in 2004, called a claim for declaring that a final judgment is unlawful (See Articles $424^{1}$ to $\left.424^{12}\right) .{ }^{16}$ This is a procedure which may be initiated only before the Supreme Court and only in relation to judgments of the civil courts. It does not lead to the annulment of the judgment or its being declared invalid. The relevant judgment is still valid and may be enforced, but it is declared to be unlawful. Such a declaration of unlawfulness may then be used only in the damages claim.

6.3. Important amendments to the above were introduced in 2010. Pursuant to amendments of the Code of Civil Procedure in 2010, the court adjudicating the question of liability incurred by a court judgment may in exceptional situations state independently whether this judgment violates the law. ${ }^{17}$

6.4. As indicated above, the claim for declaring a judgment unlawful clearly excludes Supreme Court judgments (Article $424^{1 \mathrm{a}}$ of the Code of Civil Procedure). The lack of an appropriate procedure to declare the judgment of the Supreme Court unlawful in practice makes the claim for damages against the judgment of that court impossible. Application of the test of effectiveness leads to the conclusion, and this is also something which follows directly from the judgment in the Köbler case, that such attempts to exclude liability in respect of Supreme Court judgments violate the requirements of European Union law. ${ }^{18}$ It has been pointed out in legal comments, that since there was no distinct procedure for

\footnotetext{
${ }^{15}$ It is worth to note, that the as the appropriate proceeding may be treated the procedure before the European Court of Human Rights in which the Court would declare the infringement of the Convention by the ordinary courts of even the Supreme Court. However, the case law of the Supreme Court in this respect is not uniform (see in favor judgment of 28th November 2008 r., V CSK 271/08 and contrary judgment of 15th October 2008 r., I CSK 175/08).

${ }^{16}$ Act of 22 December 2004 amending the provisions of the act-Civil Procedure Code (Journal of Laws, 2005 No. 13, item 98).

${ }^{17}$ Act of 22 July 2010 amending the act-Civil Code, the act-Code of Civil Procedure and the actBankruptcy and Reorganization Law (Journal of Laws, 2010, No. 155, item 1037).

${ }^{18}$ Case C-224/01 Köbler [2003] ECR I-10239. See: Póttorak [7], p. 175.
} 
declaring a judgment issued by the Supreme Court unlawful, in order to achieve compliance with European Union law, a court adjudicating a liability case would have to declare on its own that there had been a breach of law in the judgment of the Supreme Court. In consequence, in compliance with the procedure provided for in Art. $424^{1}$ of the Code of Civil Procedure, the Supreme Court would adjudicate on the unlawfulness of judgments issued by lower courts and at the same time a lower court hearing a liability case would adjudicate whether the Supreme Court had infringed the law. ${ }^{19}$

6.5. The amendments introduced into the Code of Civil Procedure in 2010 may be seen as having implemented a procedure for pursuing compensation claims for damages incurred as a result of Supreme Court judgments. Pursuant to these amendments, a provision was added stipulating that in the case of final judgments against which there is no remedy available, compensation for damages incurred by final judgments that were unlawful may be claimed in the complaining proceedings, without a prior declaration of the unlawfulness of the judgment. It seems that this provision will also find application in Supreme Court judgments. ${ }^{20}$ Such an interpretation, consistent with the wording of the CCP provisions, would also be a chance for achieving conformity in this respect with European Union law.

6.6. However, the Code of Civil Procedure still contains provisions which are directly contrary to the requirements of European Union law. These are provisions on excluding liability for a court judgment in respect of breaches of law concerning the establishment of facts or the assessment of evidence. Pursuant to Art. $424^{4}$ of the Code of Civil Procedure, a complaint for a declaration of unlawfulness may not be based on an allegation pertaining to establishing the facts or assessing the evidence. As may be seen in the judgment of the Court of Justice in the Traghetti case, the exclusion of liability for damage incurred as a result of errors in establishing facts or in assessing evidence by a court remains in obvious conflict with European Union legal standards. ${ }^{21}$

6.7. References to European Union law rules on state liability are very rare in the case-law of the Polish courts. It is a paradox that European Union law conditions for state liability were used by the Supreme Court as additional support for restrictive interpretations of the prerequisites for liability incurred through the

\footnotetext{
${ }^{19}$ See: Sanetra [12], p. 9.

${ }^{20}$ This interpretation is confirmed by the stand taken by the Senate explaining the amendments to the bill presented by the Lower Chamber, which says: Art. $424^{1 a} \$ 1$ and 2 pertain to the judgments of higher courts against which cassation appeals have been filed as well as the Supreme Court judgments-against which a complaint for declaration of the unlawfulness is not available. The contents of $\$ 3$ [art. Art. $424^{1 a}$ $\$ 1$ and 2] of the article in question, a little enigmatic - in the opinion of the Senate, stipulate that in the cases when there is no complaint available, compensation may be claimed without a prior declaration of the unlawfulness of the judgment. It may be concluded on the basis of such formulation of the added Art. $424^{1 a} \$ 3$ that it only refers to the judgments issued by the Supreme Court (which are referred to in \$1 and 2), whereas, according to the argumentation provided in the explanatory statement of the bill, it is a provision of fundamental significance, applicable to all final judgments against which there is no complaint available, issued on the grounds of the Code of Civil Procedure (as well as the Bankruptcy and Reorganization Law).

${ }^{21}$ Case C-173/03 Traghetti del Mediterraneo [2006], ECR I-5177.
} 
actions of courts. According to the case-law of the Court of Justice, the manifest character of an infringement of Union law by a national court is a condition for liability to arise from national courts' judgments. The manifest infringement requirement seems to be interpreted by the European Court of Justice in a similar way to the concept of gross infringement in Polish law and case-law. ${ }^{22}$ On deciding that an unlawful court judgment which may constitute grounds for compensation liability consists of a judgment "issued as a result of particularly gross misinterpretation or misapplication of law, which is self-evident and does not require an in-depth legal analysis," the Supreme Court stated that "such understanding of 'court unlawfulness' remains consistent with European Court of Justice case-law, which in the judgment of 30th September 2003 imparted an even more qualified character to the prerequisite of unlawfulness than in the case of state liability for damage sustained as a result of legislative unlawfulness (C-224/01, Gerhard Köbler vs. Austria)."23 The interpretation given by the Supreme Court of the provisions of Polish law pertaining to liability for breaches of law by courts is consistent with the conclusions that derive from European Court of Justice case-law, and thus does not violate European Union law. Yet some doubts remain as to the acceptability of this interpretation in the light of the provisions of the Code of Civil Procedure and of Article 77 of the Constitution, especially given that such interpretation in practice almost excludes the right to claim damages, as few grounds for declaring a judgment unlawful are recognized. ${ }^{24}$ Nevertheless, the notion-put forward in some Supreme Court judgments - of taking into account the individual and subjective character of adjudication and approximating the criteria of liability in respect of the actions of courts to the concept of guilt, ${ }^{25}$ goes beyond the notion of the manifest character of an infringement formulated by the Court of Justice.

\section{Different provisions on liability for civil and administrative courts}

Polish law provides for separate proceedings before administrative courts, which deal with cases pertaining to public law. Provisions regulating complaints aimed at declaring a final judgment unlawful were introduced in these proceedings much later than in the Code of Civil Proceedings. Complaints have been regulated in a similar way to they are governed under the provisions of the Code of Civil Proceedings, yet with

\footnotetext{
${ }^{22}$ See e.g. the judgment of 21 February 2007, I CNP 71/06, LEX No. 282070; judgment of 7 July 2006, I CNP 33/06, OSNC 2007, issue 2, item 35; for more, see: Bagińska [1], p. 184 and subsequent.

${ }^{23}$ The Supreme Court judgment of 4th January 2007, V CNP 132/06. In the resolution of 7 judges of 17th December 2009, III PZP 2/09, OSN 2010, No. 7-8, item 97, in turn, the European Union circumstances of liability for the actions of courts were indicated by the Supreme Court as additional support for the thesis that interpretational judgments of the Constitutional Tribunal do not constitute grounds for reopening court proceedings.

${ }^{24}$ Between 2004 and 2008 almost three thousand claims for declaring a judgment unlawful have been filed to Supreme Court, only 16 of them has been acknowledged; Baginska [2].

${ }^{25}$ See the Supreme Court judgment of 7th Feb. 2007, III CNP 53/06, unpublished.
} 
some important modifications inspired by European Union law. ${ }^{26}$ A complaint may be made against the judgments of the lower (voivodship) administrative courts if damage has been suffered in consequence of such judgments. However, Article 285a $\S 3$ of the Law on proceeding before administrative courts stipulates that such a complaint may not be made against judgments of the Supreme Administrative Court, except in situations when the unlawfulness results from gross infringement of European Union law. The complaint thus may not be made against Supreme Administrative Court decisions infringing Polish law, but it is available in the case of decisions infringing European Union law. The solution makes a distinct reference to the Court of Justice case-law, which imposes the provision in the national law of liability for damages incurred by actions of courts, including supreme courts, infringing European Union law. ${ }^{27}$ The prerequisite for the complaint provided for in the provisions of the law on proceeding before administrative courts is gross infringement of European Union law. This concept should be understood as consistent with Court of Justice case-lawi.e. with the corresponding concept of the manifest character of a infringement. At the same time the lawmakers decided that the complaint should not be available in domestic cases. Thus in practice liability for damages incurred by Supreme Administrative Court judgments infringing Polish law will be almost fully excluded. From the point of view of the principles of European Union law, such an approach, discriminating against national claims in comparison with Union ones, is admissible, yet it remains doubtful whether it is compliant with Art. 77 of the Constitution or with the provisions of the Civil Code pertaining to liability for unlawful court decisions.

\section{Appropriate proceedings in the case of liability for legislative acts}

8.1 In the case of damages caused by the issuance of a normative act, the award of compensation is possible, pursuant to Article $417^{1}$ of the Civil Code, only after the act has been declared, in appropriate proceedings, to infringe the Constitution, a ratified international treaty or an act of law. This provision was meant to refer to proceedings before the Constitutional Tribunal during the course of which the Tribunal declares the provision of law to be unconstitutional and thus null and void with erga omnes effect. However, there can be no doubt that a suitable precedent in this respect can also be (apart from the proceeding before the Constitutional Tribunal) a judgment issued in proceedings before the Court of Justice in which the Court declares in a given case that domestic law is not in compliance with European Union law. Such a judgment has of course effects different to those of judgments of the Constitutional Tribunal-it does not directly annul the contested provision of law, but for the purposes of the damages claim should be treated equivalently. Such an interpretation is all the more necessary in that the Constitutional Tribunal has refused to adjudicate in cases on the compliance of Polish law with European Union law (stating that this is part of the

\footnotetext{
${ }^{26}$ Act of 12 th February 2010 amending the act-Law on the organization of administrative courts and the act-Law on proceedings before administrative courts (Journal of Laws, 2010, No. 36, item 196).

${ }^{27}$ Case C-224/01 Köbler; Case C-173/03, Traghetti del Mediterraneo.
} 
jurisdiction of the European Court of Justice), so it is difficult to get a precedent in the form of a Constitutional Tribunal judgment in this respect. ${ }^{28}$

8.2 The above conclusion also follows from the application of the condition of equivalence leading to the obligation to guarantee the same level of protection to claims derived from the judgments issued by the Constitutional Tribunal and the European Court of Justice. In a 2010 judgment, the European Court of Justice decided a case on the equivalence of compensation claims resulting from a European Court of Justice judgment and a judgment of the Spanish Constitutional Tribunal, or more broadly - on the failure of the national law to comply with the Constitution and with European Union law. ${ }^{29}$ Compensation claims resulting from an act of law failing to comply with the Constitution were not subject to a condition of prior exhaustion of all the remedies against the adverse administrative decision issued pursuant to this act. On the other hand, pursuant to Spanish Supreme Court case-law, a complaint for compensation for damages incurred by an infringement of European Union law was conditional on the prior exhaustion of appropriate remedies, both administrative and judicial. This different treatment of Union and national claims resulted from the differences in available remedies. The national provision that constituted an infringement of the Constitution was to be presumed constitutional until it was stated that the Constitution had been infringed by the Spanish Constitutional Tribunal. Neither administrative nor judicial authorities could state this on their own and refuse to implement the controversial provision. Hence, as the Spanish government argued, the imposition upon the aggrieved party of the obligation to exhaust all available remedies in such a case, as was demanded by the Spanish government, would be disproportionate and excessive. It would require first the filing of motions with administrative authorities, subsequently with the court and then waiting for the court to raise the question of the unconstitutionality of the provision before the Constitutional Tribunal. The situation is different as regards the incompatibility of domestic law with European Union law. State authorities and courts are not only entitled but obliged to do so. ${ }^{30}$ It is thus reasonable to require that an interested party should try to assert their rights appropriately before they file a claim for compensation. Differences in treatment were also justified by the different consequences that were brought on by the judgments of the Constitutional Tribunal and the European Court of Justice, i.e. the fact that a provision may lose its legal validity as a result of the judgment issued by the Constitutional Tribunal. ${ }^{31}$ In deciding the case the European Court of Justice concluded that the claims discussed were similar. First of all, the subject of both claims was compensation for harmful actions of the State. As stated by the Court of Justice, the only difference between the claims was that one was based on a judgment issued by the Constitutional Tribunal and the other on the judgment issued by the Court of Justice. For the purposes of considering the condition of equivalence, these claims were therefore

\footnotetext{
${ }^{28}$ The Constitutional Tribunal decision of 19th December 2006, P 37/05, OTK 2006, No. 11, item 177.

${ }^{29}$ Case C-118/08 Transportes Urbanos [2010], ECR I-00635.

${ }^{30}$ Case C-118/08 Transportes Urbanos, par. 15-19.

${ }^{31}$ Case C-118/08 Transportes Urbanos, par. 20.
} 
similar. In delivering this ruling, the European Court of Justice did not accept the argument to the effect that different consequences arose from European Court of Justice judgments and the rulings issued by the Constitutional Tribunal. As for the argument about the authorities' and courts' obligations resulting from the principle of priority and the absence of such obligations and entitlements insofar as concerned the constitutionality of legal provisions - the European Court of Justice did not seem to accept this argument, either. The European Court of Justice relied first of all on the argument that both claims had the same content, character and origin. For the European Court of Justice, the last characteristic seemed to settle the question of the claims' similarity. It even prevailed over the argumentation about the easier path of pursuing European Union law claims by individuals than domestic ones due to the obligations imposed upon state organs and courts by the principle of supremacy.

8.3 The above ruling indicates that, assuming claims derived from the Polish Constitutional Tribunal case-law and the one of the Court of Justice are similar, rulings by both courts should offer the same prospects of obtaining compensation for sustained damages.

\section{Conclusion}

The new rules on state liability in Polish law draw their inspiration from European Union rules. Broadly speaking, they seem in compliance with the requirements which derive from the case-law of the Court of Justice. However, their restrictive interpretation by the Polish courts in many cases does not permit the enforcement of the claim for damages in practice. The main problem has been the attempt by the legislator followed by case-law to exclude liability in respect of Supreme Court judgments. The amendments of 2010 in this respect gave however a chance to remedy this incompatibility via the consistent interpretation of Polish law with European Union law. The other main problem consists of the conditions for liability for court decisions. The legal provisions themselves do not establish any qualifications for infringements of law. However Supreme Court case-law, decided with reference to European Court of Justice jurisprudence, limits declarations of unlawfulness to manifest breaches of law in court judgments. The application of the manifest infringement condition results in successful claims being very exceptional. This proves that the right to obtain damages in the event of the infringement of European Union law by a court decision is still ineffective.

Open Access This article is distributed under the terms of the Creative Commons Attribution License which permits any use, distribution, and reproduction in any medium, provided the original author(s) and the source are credited.

\section{References}

1. Bagińska, E.: Odpowiedzialność odszkodowawcza administracji. In: Hauser, R., Niewiadomski Wróbel, Z.A. (eds.) System Prawa Administracyjnego, vol. 12. C.H. Beck, Warszawa (2010) 
2. Bagińska, E.: Odpowiedzialność Skarbu Państwa za szkody wyrządzone przez wydanie niezgodnego z prawem orzeczenia sądu. Transform. Prawa Prywat. 3 (2011). ISSN 1641-1609

3. Górka, M.: Zasada odpowiedzialności odszkodowawczej państwa za naruszenie prawa wspólnotowego, Prz. Prawa Eur. 1(2) (1997)

4. Kakouris, C.N.: Do the member states possess judicial procedural 'Autonomy'? Common Mkt. L. Rev. 34 (1997)

5. Pajor, T.: Odpowiedzialność państwa członkowskiego Unii Europejskiej za szkodę wyrządzoną jednostce wskutek naruszenia prawa wspólnotowego. In: Studia z Prawa Prywatnego. Łódź (1997). Księga pamiątkowa ku czci Profesor Biruty Lewaszkiewicz-Petrykowskiej

6. Półtorak, N.: Roszczenia odszkodowawcze z tytułu naruszenia prawa unijnego przez państwa członkowskie. In: Stosowanie Prawa Unii Europejskiej przez Sądy. Vol. I, 2nd edn. Warszawa (2010)

7. Półtorak, N.: Glosa do wyroku Europejskiego Trybunału Sprawiedliwości w sprawie C-224/01, Gerhard Köbler p. Austria, Kwart. Prawa Publicznego 4 (2003)

8. Półtorak, N.: Ochrona Uprawnień Wynikających z Prawa Unii Europejskiej w Postępowaniach Krajowych. Warszawa (2010)

9. Półtorak, N.: Odpowiedzialność Odszkodowawcza Państwa w Prawie Wspólnot Europejskich. Kraków (2002)

10. Póltorak, N.: Odpowiedzialność skarbu państwa z tytułu naruszenia prawa unii Europejskiej—czy polskie prawo i orzecznictwo respektują wymogi prawa unijneg? Transform. Prawa Prywat. 3(2011)

11. Sadowski, W.: Granice odpowiedzialności odszkodowawczej państw członkowskich za orzeczenia sądów_glosa do wyroku ETS z 13.6.2006 r. w sprawie C-173/03, Traghetti del Mediterraneo. Eur. Prz. Sąndowy 11 (2006)

12. Sanetra, W.: In: W kwestii odpowiedzialności za wyrządzenie szkody przez wydanie orzeczenia niezgodnego z prawem wspólnotowym. Eur. Prz. Sąndowy 3 (2006)

13. Sanetra, W.: W kwestii odpowiedzialności za wyrządzenie szkody przez wydanie orzeczenia niezgodnego z prawem wspólnotowym. Eur. Prz. Sąndowy 3 (2006)

14. Sanetra, W.: Za jakie naruszenia prawa wspólnotowego przez sąd najwyższego szczebla należy się odszkodowanie: uwagi na marginesie wyroku ETS w sprawie Traghetti. Eur. Prz. Sa̧ndowy (2006)

15. Tokarzewska, J.: Odpowiedzialność odszkodowawcza państw członkowskich: Unii Europejskiej wobec podmiotów prywatnych. Państ. Prawo 12 (1998)

16. Van Gerven, W.: Of rights, remedies and procedures. Common Mkt. L. Rev. 37 (2000)

17. Zatorska, J.: Odpowiedzialność odszkodowawcza państwa członkowskiego za działania władzy sądowniczej na przykładzie Polski i Francji. Eur. Prz. Sa̧ndowy 7 (2008) 